\title{
PUBLIC CONSCIOUSNESS AND ITS SYNONYMS: A LITERATURE REVIEW
}

\author{
M.O. Nassimov
}

\begin{abstract}
The problem of the formation and development of public consciousness of society is relevant in the context of modern global phenomena and a new technological order. Since human resources are a special potential of the state, it is important to develop the public consciousness of society. It is necessary to instill in people the norms of benevolence and humanism in shaping the quality and ethics of the nation for the prosperity of all aspects of national development. Thus, the foundation is laid for effective socialization through the main social institutions. For this, the development of public consciousness is very important and everyone should be involved in this development. At the same time, the development of the population, society and their participation in decision-making gives them a sense of cooperation with the state. It is clear that such a situation will contribute to the sustainable development of the country. In this article presents a literary review of public consciousness and its synonyms. The concepts of "social consciousness", "public awareness", "public conscience" and "social conscience" were taken as synonyms and was analyzed each concept. Conceptually, attention was paid to the results that were published for the first time and published in recent years.

Keywords: Spiritual Modernization, Public Consciousness, Social Consciousness, Public Awareness, Social Sciences, Arts and Humanities.

Kyzylorda University
Bolashak, Kyzylorda,
Kazakhstan
Corresponding Author:
Nassimov M.,
nasimov_m@mail.ru

Reference to this article:
M. Nassimov. Public
Consciousness and its
Synonyms: a Literature
Review // Adam alemi. -
2021. - No. 4 (09).
- P. 114-122.

Kyzylorda University Bolashak, Kyzylorda, Kazakhstan

Corresponding Author: Nassimov M., nasimov_m@mail.ru

Reference to this article:

M. Nassimov. Public

Consciousness and its

Synonyms: a Literature

Review // Adam alemi. -

2021. - No. 4 (09).
\end{abstract}

\section{Қоғамдық сана және оның синонимдері: әдеби шолу}

\begin{abstract}
Аннотация. Қазіргі таңдағы жаһандық құбылыстар мен жаңа технологиялық тәртіп шарттарында қоғамның қоғамдық санасын қалыптастыру мен дамыту мәселесі өзекті болып табылады. Адами ресурстар мемлекеттің ерекше әлеуеті болғандықтан қоғамның қоғамдық санасын дамыту маңызды саналады. Ұлттық дамудың барлық қырларының өркендеуі жолындағы ұлттың сапасы мен әдебін қалыптастыру барысында халыққа ізгілік пен адамгершілік нормаларын сіңдіру қажет. Осылайша негізгі әлеуметтік институттар арқылы тиімді әлеуметтендірудің негізі қаланады. Бұл үшін қоғамдық сананың дамуы өте маңызды және осы даму жолына әр адам қатысуы тиіс. Сонымен бірге, халықтың, қоғамның дамуы мен шешімдер қабылдауға қатысуы олардың мемлекетпен ынтымақтастығы сезімін береді. Мұндай ахуал мемлекеттің тұрақты дамуына түрткі болатындығы анық. Берілген мақалада қоғамдық сана және оның синонимдеріне әдеби шолу жасалады. Синонимдер ретінде «social consciousness», "public awareness», «public conscience» және «social conscience» түсініктері алынып, әр ұғымға талдау жасалды. Түсініктер бойынша ең алғаш жарияланған және соңғы жылдары жарық көрген тұжырымдарға мән берілді.
\end{abstract}

Түйін сөздер: рухани жаңғыру, қоғамдық сана, әлеуметтік (қоғамдық) сана, қоғамның хабардар болуы, әлеуметтік ғылымдар, өнер және гуманитарлық ғылымдар. 


\title{
Общественное сознание и его синонимы: литературный обзор
}

\begin{abstract}
Аннотация. Проблема формирования и развития общественного сознания общества актуальна в условиях современных глобальных явлений и нового технологического уклада. Поскольку человеческие ресурсы - это особый потенциал государства, важно развивать общественное сознание. Необходимо прививать людям нормы доброжелательности и гуманизма в формировании качества и этики нации для процветания всех аспектов национального развития. Таким образом, закладывается фундамент для эффективной социализации через основные социальные институты. Для этого очень важен развитие общественного сознания и каждый должен быть вовлечен в это развитие. В то же время развитие населения, общества и их участие в принятии решений дает им ощущение сотрудничества с государством. Понятно, что такая ситуация будет способствовать устойчивому развитию страны. В статье представлен литературный обзор общественного сознания и его синонимов. Понятия «social consciousness», «public awareness», «public conscience» и «social conscience» были взяты как синонимы и проанализировали каждое понятие. В концептуальном плане внимание было уделено результатам, которые были опубликованы впервые и опубликованы в последние годы.
\end{abstract}

Ключевые слова: духовная модернизация, общественное сознание, социальное сознание, осведомленность общественности, социальные науки, искусство и гуманитарные науки.

\section{Introduction}

In general, foreign scientists along with the concept of "spiritual modernization" (Kazakh: "рухани жаңғыру"; Russian: "духовная модернизация") widely use the concept of "spiritual renewal" (Kazakh: "рухани жаңарту"; Russian: "духовное обновление") and "spiritual revival" (Kazakh: "рухани жаңару, өрлеу"; Russian: "духовное возрождение"). When defining the category of "spiritual modernization", we observed a great use of the concept of "spiritual renewal". For example, on the basis of Scopus, 4 literatures were found that used the concept of "spiritual modernization" and the concept of "spiritual renewal" was used by 106 studies in the field of arts and humanities, 52 in social sciences. Accordingly, "spiritual revival" in arts and humanities - 35, in social sciences - 26 . The problems of spiritual modernization were viewed as a revolutionary form [1], in the context of the war influence [2] and on the issues of spiritual modernization of student youth [3]. It should be noted that the concept of "spiritual modernization" was first used by Scopus in 2009. After the introduction of the Rukhani Zhangyru program in Kazakhstan domestic scientists began to publish research results on these issues. In general, it seems to us that the research data was published in Kazakh and Russian languages. The thing is that the number of studies on this issue published in journals indexed by Scopus reaches $3[4 ; 5 ; 6]$.

1979 was the first time the concept of "spiritual renewal" was used, where the authors defined intellectual, physical or spiritual renewal through exercises related to reading [7]. It should be noted that most of the research is related to religion $[8 ; 9$; $10]$. More modern research examines the issues of secularization and post-secularity [11], the influence of Greek spirituality on Russian culture [12], etc. Bowpitt [13] defines 1998 charity as an instrument of spiritual revival. Rzepa [14, p. 89-136] examines the spiritual revival brought by the World War 1 and its impact on the religious and political discourse of the interwar period.

Therefore, it is very important to highlight the concept of public consciousness and its synonyms. For this, we introduced such concepts as "social consciousness" (Kazakh: "әлеуметтік (қоғамдық) сана"; Russian: "социальное (общественное) сознание"), "public awareness" (Kazakh: "қоғамның хабардар болуы"; Russian: "осведомленность общественности"), "public conscience" (Kazakh: "қоғамдық

$$
\text { https://adamalemijournal.com } \mid 115
$$


сана"; Russian: "общественное сознание") and "social conscience" (Kazakh: "қоғамдық сана"; Russian: "общественное сознание") which are interrelated. We want to determine the quantitative and qualitative level of the use of these words in scientific literature. We would also like to know what problems these concepts are used to solve.

\section{Methodology}

Empirical research data consists of theoretical and practical work on the problem. For this we used data from Scopus materials. 1) Comparative analysis made it possible to clarify the meaning and characteristics of the concept under study. 2) The method of historical analysis of the research helped to determine the genesis of the concept. 3) The method of systems analysis made it possible to obtain a detailed explanation of the subject of research. 4) The method of structural analysis helped to determine the current state of public consciousness. The study took into account the theoretical concepts of several scientists.

During the study of the problem we found these materials (Table 1). In order to clarify the data obtained, we divided into areas social sciences, arts and humanities.

Table 1 - Public consciousness and its synonyms*

\begin{tabular}{|c|c|c|}
\hline & Social sciences & Arts and humanities \\
\hline public consciousness & 555 & 341 \\
\hline social consciousness & 489 & 303 \\
\hline public awareness & 2861 & 634 \\
\hline public conscience & 66 & 34 \\
\hline social conscience & 143 & 99 \\
\hline
\end{tabular}

'Source: Scopus data from 06 September 2021.

Public Consciousness and Social Consciousness: Main Research Problems

In general, the English concepts Public and Social are used interchangeably and have similar meanings. This is a sign that the concepts of Public and Social are common.

The first mention of public consciousness was in 1960 and Weaver [15] identified it with the accomplishments of higher education. According to the author, public consciousness is a serious national concern. In the 60 s of the last century, the unexpected results of social and technological change are characterized by a change in the environment. Although these questions were raised sixty years ago, they are stillactual and modern technological changes are even more dangerous. Therefore, the creation of the desired environment depends on the public consciousness of citizens and their reasonable concern [16].

The following aspects of public consciousness are covered in scientific literature (in 2021):
- youth discourses and practices of resistance [17];

- psychologisation of counterextremism [18];

- economy and society in COVID pandemic (here the author indicates many latent tendencies, tensions and divisions which shows public consciousness) [19];

capitalness in both public consciousness (authors argue, that the capital is also an important element that affecting the relations between the Center and the Periphery and the regional policy of the country) [20];

problems of geo-eco-ideology in the modern world (according to the authors, geo-eco-ideology, as a result of modern public consciousness determines the ecological state, ecological political sovereignty, justice and responsibility) [21, p. 213-225];

- on the problem of European parties and political groups (the authors demonstrate that they play an invisible role in the public consciousness of the member states) [22, p. 251-265]; 
- cultural heritage of a poster (the author proves the role of the poster in the formation of public consciousness and its powerful influence on public opinion) [23].

During the analysis, we noticed that the concept of "Public consciousness" is often used by scientists from the post-Soviet space. This category is very rarely used by foreign authors in their scientific publications.

We noticed that the concept of "social consciousness" was studied earlier than "public consciousness". This is the first time Hodge is conducting research, and its subject is education. Hodge, examining the development of social consciousness in Sunday school, comes to the conclusion that social consciousness is the consciousness of an individual. According to the scientist, the individual should avoid self-centered and irreligiousness [24]. In addition, it is very noticeable that the early studies were mainly concerned with educational problems:

- on the necessity for a scientific study of social consciousness in education (Boston meeting of the American Association for the Advancement of Science) [25];

- on the role of the school as a means of developing social consciousness and social ideals in children [26];

rating school behavior and attitudes in the elementary school [27].

In 2021, 36 studies examined the problem of social consciousness. Soman [28] argues that social consciousness is shaped by moral and political hegemonic power structures. This could mean that power can influence our social consciousness. Social networks, which have firmly entered the life of people and a unique phenomenon of the twentyfirst century, also affects the common social consciousness. Mar García-de los Salmones, Herrero and Martínez [29] argue that social consciousness influences the usefulness of information and attitudes towards behavior. The most important thing in social networks is information. According to members of society, information from social networks can have a negative or positive effect on mood, information from social networks can help or not a person's development, or some are sure that viewing information and communicating on the Internet does not affect people in any way.

\section{Public Awareness and its Main Problems}

Social dialogue and public awareness should always be a priority for the authorities. Many techniques and methods can be used to inform the public, raise public awareness. For example, scientists noted that in addition to immediate self-isolation during COVID-19, public awareness of the symptoms of COVID-19 is an effective measure to prevent the spread of the epidemic.

Among the earliest publications on the concept of public awareness are Bell's works on the mental measurements in education. Bell [30] emphasizes the need to raise public awareness of the practical value of mental measurements in education. In another Bell's [31] scientific work, focusing on public awareness of the reliability of the use of mental tests and the need to supplement them with tests and scales in every high school subject reveals a clearer picture.

Until the 60 s of the last century, the concept of public awareness was mainly considered in psychology and law. For example, Clausen et al. [32] considers the problem in the context of mental health. Public awareness of how to combat organized crime can lead to effective law enforcement [33]. The effectiveness of law enforcement is understood as the achievement of goals by a specific legal norm, institution of law, branch of law, through the issuance of law enforcement acts on the basis of compliance with the principles of law enforcement and ensuring their real implementation. Larmon [34] calling for public awareness, responsibility and action points to a rapid rise in crime rates. Here the question of the moral norms of society is already relevant. Moral norms are similar to legal norms. The thing is that they play the role of the main mechanism by which formed human behavior.

During the research, we were interested in what topics with the keyword "Public awareness" scientific results were published in 2021:

disclosure of environmental information (promotion of public awareness helps to strengthen information disclosure on various environmental problems in the region) [35];

https://adamalemijournal.com

ISSN 1999-5849 
- investigative journalism as a subject of impact on journalism (authors disclose policy changes from public awareness and dialogue) [36];

- misinformation on social media (public awareness was negatively impacted by social media posts that disseminated false information) [37];

- active involvement of fathers in childrearing (the authors argue that there is a necessary to raise public awareness of the role of the father and his inclusion in all aspects of family life) [38];

- educational attainment (according to the authors, formal education increases public awareness and concern) [39];

- cybercrime with industrial espionage (public awareness can positively impact the prevention of industrial espionage and online crime) [40];

- knowledge, attitudes and precautions regarding fatal diseases (e.g. COVID-19, where medical students can play an important role in increasing public awareness of precautions against the virus) [41].

As can be seen from this analysis, scientists are considering this problem from different angles. Possibilities for solving environmental problems are closely related to the availability of environmental information. The environmental policy of the state ensures the exercise of the rights of citizens to a healthy environment through the development of environmental legislation, including the issue of free access to environmental information. Investigative journalism as an activity of collecting and interpreting information characterizes a systematic and long-term study of the problem. These investigations are usually devoted to high-profile crimes and various scandals, the activities of famous organizations, etc. False information has always existed. Misinformation always leads to manipulation of public consciousness. Therefore, when disseminating information on social networks, each member of society should think about whether it is reliably or not. The role of the father in the upbringing of children is of great importance. The father is also the bearer of social norms and requirements in relation to the child. Therefore, fathers are not only breadwinners in the family, they must take an active part in the process of raising children and developing them as individuals. The educational attainment should be always be higher. Schools that provide secondary education and higher education should provide a set of knowledge, skills and values that will be useful to a person in later life. Cybercrime in the global world is becoming large scale. It is no secret to anyone, today an attentive and careful attitude to your credentials and personal data can also significantly contribute to protection from intruders. Knowledge, attitudes and precautions regarding each issue also affect public consciousness.

\section{Public Conscience and Social Conscience: Main Research Problems}

In science, along with the category of public consciousness is also used public conscience and social conscience. In 1931 Foster measures public conscience and common-carriers [42]. Scandals of various types always give rise to public consciousness and undermine their position in society. For example, the uproar with the police caused a public outcry and diminished public confidence [43]. Ashby and Anderson have always used public conscience in their research, for example, on the protection of the environment from pollution [44] and the smoke abatement [45]. This shows the universality of the concept of public conscience.

In recent years, researchers have considered such problems associated with public conscience:

- public intellectual life conception (appeal to the public conscience of intellectuals) [46];

- creative destruction and social (re) construction of heritage (author argue about the impact of war, terrorist attacks and climate change on public conscience) [47];

- research work of the scientific society (study awakens public conscience, gives impetus to social development) [48];

- religious freedom (essence of public conscience, private equality and public reason) [49];

- civil-military cooperation (entrench of various movements in the public conscience) [50, p. 549-563];

All scientists live a social intellectual life. Their scientific works should be worked out in the preparation of their hypotheses 
and should be useful to society and the state. Creative destruction is everyone's constructive, originative work. He continuously removes every structure, destroys the old system and creates a new one. And all this is interconnected with the research work of the scientific community.

Peabody [51], in his 1909 work, connects social consciousness with religious life. According to the author: "Religious education, it may be said, deals with the child, the individual, the Church; social duty deals with the community, the industrial order, the State. Religious education leads to a better knowledge of God; social duty leads to a better service of man" [51, p. 1]. It should be noted here, that social duty is a duty to society, following the moral values of society. Day [52], in his pedagogical opinions, examines the evolution of social conscience using the example of small boy's newspapers. According to the author, the environment is important here and he is not helpless, his creations are associated with his social development. Troncoso [53] argues, that constitutions where there is social content reflects social conscience. In our opinion, social content allows you to develop skills, improve competence, develop personal qualities and creative individuality, activating the process of personal development.

Of course, we were interested in what topics have been raised with the problem of social conscience in recent years:

- poetics of resistance (poetic works show ideological dissent with different problems) [54];

- social support (mobilization of voluntary social helpers) [55];

- social justice and sustainable development (social conscience mobilizes different movements that agitating for social change) [56, p. 1-18];

- role of social entrepreneurship for youth purpose development (social entrepreneurship contributes to social conscience) [57];

relationship between social entrepreneurship, education and work (social conscience is formed by new sites of education) [58].

Every creative person has his own resistance and his technique can be supported by an ideological task. The policy of resistance occurs for various reasons. Creative resistance always occurs by demanding the values of modern society from the author. Social support doesn't have to be direct, as in the form of pensions or benefits to the poor, but there can be various indirect forms as in the volunteer assistance in household matters. In addition, in higher education to paying attention to education and science, it is also necessary to turn to social support for students. This can be in the form of creating an environment for sports (fitness rooms), art, etc. for personal development in their free time from study. Social justice and sustainable development should always be focus on the person. Humanity has achieved colossal results in science and technology, but most people continue to live in frightening conditions. Therefore, it is very important to create spiritual, cultural, social, economic and political conditions for life, which guarantees the realization of the potential of members of society. Social entrepreneurship is aimed at solving social problems and its main features are social impact, innovativeness and financial sustainability.

\section{Conclusion}

The study shows that the future of every country and society is closely related to the formation of public consciousness. Of course, it is impossible to analyze public consciousness and its synonyms in one article. In general, scientists from post-Soviet countries use the English equivalents of some words in their own way. For example, the concept of "National consciousness" (Kazakh: "ұлттық сана"; Russian: "национальное сознание") by foreign scientists often studied using the concept of "National identity" (Kazakh: "ұлттық бірегейлік"; Russian: "национальная идентичность"). In this case, the main difference may be the use of the concept of public consciousness.

The worldview in the public consciousness contributes to the formation of a person's spiritual needs. The 21st century has led to historical changes in worldview paradigms in the development of public consciousness. The worldview of a person in a globalized social space is associated with public consciousness. Many factors in society and the environment influence the formation of a worldview. For example, upheavals in social 
systems causing political, ideological, moral and ethical, national crises change the lives of people and their public consciousness. Therefore, in order to determine the place of the worldview in the public consciousness, it is necessary to look for a way out of the spiritual crisis. We also consider it important to develop a set of measures aimed at reducing the spiritual crisis.

Humanitarian sciences a special place in changing public consciousness, since they shape a person's view of the world. The peculiarity of humanitarian education is that it is aimed at finding the inner spiritual world of each person. This shows that all areas of humanitarian education are filled with worldview ideas. By public consciousness, we mean the consciousness of the individual formed in society and the system of social rules and principles. Public consciousness is characterized by its relativity, historicity, continuity of opinions and influence on citizens. Consequently, the development of worldview, knowledge, actions, social behavior, legal views, social life and human culture consists in the formation of these principles of social consciousness.

\section{References}

1 Butler M. God's campesinos? Mexico's revolutionary church in the countryside // Bulletin of Latin American Research. 2009, 28(2). - P. 165-184.

2 Samokhin K. V. War Influence on Spirit Development of Russian Socium during 18th -the first half of the 19th centuries: Modernization or protomodernization // Bylye Gody. 2019, 53(3). - P. 986-997.

3 Zhetpisbayeva B.A., Zhilbayev Z.O., Syrymbetova L.S., Dyakov D.V., Muratova L.M. Spiritual modernisation of student youth //Journal of Siberian Federal University Humanities and Social Sciences. 2020, 13(2). P. 258-267.

4 Zhumagulova V., Kazhigaliyeva G., Onalbayeva A., Khankishiyeva E., Zadayeva A. Main methods of the impact of the Kazakhstan Russian-language media on modernization // Opcion. 2019, 35 (Special Issue 23). - P. 11551170.

5 Tuleuova K., Sheryazdanova K., Alpeisov A. Rukhani zhangyru as the cornerstone in the foreign cultural policy of Kazakhstan // Opcion. 2019, 35(90-2). - P. 668-683.

6 Zhumagulova V.I., Kazhigalieva G.A.,
Khankishiyeva E.M., Orynkhanova G.A., Zadayeva A.A. The concept of people and new ideological concepts in Kazakhstan's media // Opcion. 2020, 36(91). - P. 601-621.

7 Gentile L.M., McMillan M. Reading: A means of renewal for the aged // Educational Gerontology. 1979, 4(3). - P. 215-222.

8 Bundy D. Louis Dalliere: Apologist for Pentecostalism in France and Belgium, 19321939 // Pneuma. 1988, 10(1-2). - P. 85-115.

9 Verhack I. Terugkeer van de religie? // Bijdragen. 1992, 53(2). - P. 152-181.

10 Howard D.L. Mrs Dalloway: Virginia Woolf's redemptive cycle // Literature and Theology. 1998, 12(2). - P. 149-158.

11 Jagiełło J. Beyond secularization and post-secularity - Joseph Ratzinger's and Józef Tischner's concept of a breakthrough // Religions. 2021, 12(7). - P. 530.

12 Zozulak J. The influence of Greek spirituality on Russian culture // Religions. 2021, 12(7). - P. 455.

13 Bowpitt G. Evangelical christianity, secular humanism, and the genesis of British social work // British Journal of Social Work. 1998, 28(5). - P. 675-693.

14 Rzepa J. Spiritualising the war: Religion, conflict, and politics. In: Palgrave Studies in Modern European Literature / edited by B. Hutchinson, S. Weller. - Palgrave Macmillan, 2021.

15 Weaver J.C. What federal funds mean to the universities today // The Annals of the American Academy of Political and Social Science. 1960, 327(1). - P. 114-122.

16 Blumenfeld $H$. The role of design // Journal of the American Planning Association. 1967, 33(5). - P. 304-310.

17 Cordova G. Challenging hegemony, imaging alternatives. Everyday youth discourses and practices of resistance in contemporary Tunisia // Journal of North African Studies. 2021, 26(2). - P. 337-355.

18 Younis T.The psychologisation of counter-extremism: unpacking PREVENT // Race and Class. 2021, 62(3). - P. 37-60.

19 Langley P. Economy and society in COVID times // Economy and Society. 2021, 50(2). - P. 149-157.

20 Okunev I., Ostapenko G. Symbolism of capital cities: Field research of stateless capitals // Territorio. 2021, 94. - P. 167-178.

21 Belous V., Volkov V., Baltovskij L. Geoeco-ideology: Modern world in search of common values. In: Proceedings of Topical Issues in International Political Geography / edited by R. Bolgov, et al., Springer Geography. - Cham: Springer, 2021. 
22 Wurst A.-K., Schlosser K., Haßler J. European party groups: transnational continuation or complement of European national parties? In: Political Campaigning and Communication / edited by J. Haßler, M. Magin, U. Russmann, V. Fenoll. - Springer, 2021.

23 Pryshchenko S.V. Cultural heritage of a poster: Communicative and creative experience // Creativity Studies. 2021, 14(1). - P. 18-33.

24 Hodge R.M. The development of social consciousness in the sunday school // Pedagogical Seminary. 1909, 16(4). - P. 523529.

25 Dingham W. V. D. Educational psychology at the Boston meeting of the American Association for the Advancement of Science // Journal of Educational Psychology. 1910, 1(3). - P. 159-167.

26 Dewey J. The school as a means of developing a social consciousness and social ideals in children // Journal of Social Forces. 1923, 1(5). - P. 513-517.

27 Van Alstyne D. A new scale for rating school behavior and attitudes in the elementary school // Journal of Educational Psychology. 1936, 27(9). - P. 677-693.

28 Soman N. Hegemony, exclusion and equivocal identities: Reflections on Israel's Arab minority in sayed Kashua's dancing Arabs // Rupkatha Journal on Interdisciplinary Studies in Humanities. 2021, 12(5). - P. 1-9.

29 Mar García-de los Salmones M., Herrero A., Martínez P. Determinants of electronic wordof-mouth on social networking sites about negative news on CSR // Journal of Business Ethics. 2021, 171(3). - P. 583-597.

30 Bell J. C. Mental measurements in education // Journal of Educational Psychology. 1919, 10(1). - P. 54-55.

31 Bell J. C. Mental tests and college entrance // Journal of Educational Psychology. 1919, 10(3). - P. 168-169.

32 Clausen J. A., Nunnally J.C., Star S.A., Gurin G., Schreiber J., Halpert H. Public awareness and perception of the problems of mental health // Public Opinion Quarterly. 1957, 21(3). - P. 418421.

33 Kennedy R. F. Three weapons against organized crime // Crime \& Delinquency. 1962, 8(4). - P. 321-324.

34 Larmon S.S. A look toward the prevention of crime and delinquency // Crime \& Delinquency. 1965, 11(1). - P. 1-7.

35 Li N., Shi B., Kang R. Information disclosure, coal withdrawal and carbon emissions reductions: A policy test based on China's environmental information disclosure // Sustainability. 2021, 13(171). - P. 9758.
36 Dahmen N., Walth B. Revealing problems, pointing fingers, and creating impact A survey of investigative reporters/editors regarding journalistic impact // Newspaper Research Journal. 2021, 42(3). - P. 300-313.

37. Forati A.M., Ghose R. Geospatial analysis of misinformation in COVID-19 related tweets // Applied Geography. 2021, 133. - 102473.

38 Nemet M.B., Vrdoljak G., Budaić V.L. Parenting style and the active involvement of fathers in child-rearing // Jahr. 2021, 12(1). - P. 107-125.

39 Olivos F., Palomo-Vélez G., OlivosJara P., Liu M. Educational attainment and environmental concern in China: An instrumental variable approach // Asian Journal of Social Psychology. 2021, 24(2). - P. 156-168.

40 Paek S.-Y., Nalla M. K., Chun Y.-T., Lee J. The perceived importance of cybercrime control among police officers: Implications for combatting industrial espionage // Sustainability. 2021, 13(82). - P. 4351.

41 AL-Rawajfah O. M., Al-Mugeed K. A., Alaloul F., Al-Rajaibi H. M., Al Omari O. COVID-19 knowledge, attitude, and precautionary practices among health professional students in Oman // Nurse Education in Practice. 2021, 52. - 103041.

42 Foster O. D. Public conscience and common-carriers // Religious Education. 1931, 26(8). - P. 627-630.

43 Ingersoll J. E. The Police Scandal Syndrome: Conditions Leading to an Apparent Breakdown in Police Service // Crime \& Delinquency. 1964, 10(3). - P. 269-275.

44 Ashby L., Anderson M. Forecasting change in industry and the economy with restricted resources // Interdisciplinary Science Reviews. 1976, 1(4). - P. 279-290.

45 Ashby L., Anderson M. Studies in the politics of environmental protection: The historical roots of the british clean air act, 1956: III. The ripening of public opinion, 1898-1952 // Interdisciplinary Science Reviews. 1977, 2(3). - P. 190- 206.

46 Fatsis L. Becoming public characters, not public intellectuals: Notes towards an alternative conception of public intellectual life // European Journal of Social Theory. 2018, 21(3). - P. 267-287.

47 Avrami E. Creative destruction and the social (re) construction of heritage // International Journal of Cultural Property. 2020, 27(2). - P. 215-237.

48 Tsyuryumov A. V., Timofeeva E. G., Kurapov A. A., Lebedev S. V. Peter the great society for the study of Astrakhan region: Writings of its members on Kalmyk history 
and culture, last quarter of the 19th- Early 20thcenturies // Oriental Studies. 2020, 13(5). P. 1218-1233.

49 McGravey K. Religious freedom: Public conscience, private equality, and public reason // Journal of Church and State. 2020, 62(4). - P. 630-653.

50 Tar U.A., Bala B. Civil-military cooperation: Joint military-civilian operations in counterterrorism and counterinsurgency in North-East Nigeria. In: The Routledge Handbook of Counterterrorism and Counterinsurgency in Africa / edited by U.A. Tar. - Routledge, 2021.

51 Peabody F.G. The social conscience and the religious life // Religious Education. 1909, 4(1). - P. 1-6.

52 Day L.C. A small boy's newspapers and the evolution of a social conscience // Pedagogical Seminary. 1917, 24(2). - P. 180-203.

53 Troncoso M. P. The social content of latin american constitutions // Social Forces. 1942, 21(1). - P. 100-106.

\section{INFORMATION ABOUT AUTHORS}

Murat Nassimov

Мұрат Өрленбайұлы Насимов

Мурат Орленбаевич Насимов
54 Navarro I. M. Notes on a reading of the poetic of resistance in Carmelina SánchezCutillas and Vicent Andrés Estellés // SCRIPTA. 2021, 17. - P. 504-519.

55 Arnfjord S. Greenland's emerging social conscience - Voluntary food delivery to people experiencing homelessness in Nuuk // Qualitative Social Work. 2021, 20(1-2). - P. 433-438.

56 Kavanagh A. M., Waldron F., Mallon B. An introduction. In: Teaching for Social Justice and Sustainable Development Across the Primary Curriculum / edited by A.M. Kavanagh, F. Waldron, B. Mallon. - Routledge, 2021.

57 Ong D., Shang L., Chandra Y., Hamidi M., Wahab H. A. The role of social entrepreneurship for youth purpose development // Journal of Asian Public Policy. 2021, 14(2). - P. 272-290.

58 Gerrard J. Social enterprise, education and work: entrepreneurialism on the margins // Journal of Education Policy. 2019, 34(6). P. 771-788.

Associate Professor, Candidate of Political Sciences, Research Institute Bolashak, Kyzylorda, Kazakhstan

қауымдастырылған профессор, саяси ғылымдарының кандидаты, «Болашақ» Ғылыми-зерттеу институты, Қызылорда, Қазақстан

ассоциированный профессор, кандидат политических наук, Научно-исследовательский институт «Болашак», Кызылорда, Казахстан 